Journal of Engineering and Applied Sciences 14 (8): 2504-2512, 2019

ISSN: 1816-949X

(C) Medwell Journals, 2019

\title{
Biotransformation of Fruti-Horticultural Agro-Industrial Residues Using Efficient Microorganisms (EM) in Riobamba (Ecuador)
}

\author{
Clemencia O. Merino, I.F. Bayas-Morejon, M. Changoluisa, Maria P. Lema, Cecilia Gomez, \\ L. Verdezoto, I. Moreno, Myriam C. Merino, Rosa A. Tigre and Washington Donato \\ Centro de Investigacion y Desarrollo Biotecnologico, Departamento de Investigacion, \\ Facultad de Ciencias Agropecuarias Recursos Naturales y del Ambiente, \\ Universidad Estatal de Bolivar, CP-020150 Guaranda, Ecuador
}

\begin{abstract}
The search for biotechnological alternatives for the use of organic waste in the horticultural process is a current problem. In this investigation, the biotransformation of tomato peels (Solanum lycopersicum L.), naranjilla (Solanum quitoense), tamarind (Tamarindus indica), potatoes (Solanum tuberosum) and cauliflower (Brassica oleracea L.) was evaluated. Residues, subjected to aerobic fermentation with Effective Microorganisms (EM): photosynthetic bacteria (Rhodopseudomonas spp.,), lactic acid bacteria (Lactobacillus spp.,) (EM-1) and yeast (Saccharomyces spp.,). Two percentages of EM-A and three doses of agro-industrial wastes were used to produce biofertilizer in this the $\mathrm{pH}$ (3.9) and the carbon/nitrogen ratio were determined they were placed with in the regulations. The biofertilizer yield was $2.94 \mathrm{~kg} / \mathrm{m}^{2}$. A physical-chemical analysis was carried out on the bio-fertilizer, evaluating the sensory indicators: color, smell and texture, the most outstanding physicochemical characteristics were presented in the T6 treatment (A3B2) which corresponds to $40 \%$ fruit waste plus $40 \%$ of vegetables plus $20 \%$ of substrate to $10 \%$ of EM-A. The chemical analysis of the best treatment was T2 (80\% of fruit waste plus $20 \%$ of substrate to $10 \%$ of EM-A) with concentrations of macro and micro elements of N: 24600; K: 15800; Ca: 12800; Mg: 4300; P: 3900; Faith: 3300; Mn: 92.39; Zn: 69.05; Cu: 27.99; B: $15.55 ; \mathrm{Mo}: 0.96 \mathrm{mg} / \mathrm{kg}$, acceptable ranges according to current regulations including the microbial population. Finally, the cost/benefit analysis of $0.454 \mathrm{~kg}$ of biofertilizer at 1.25 was established with a profit of 0.30 cents.
\end{abstract}

Key words: EM-A, EM-1, biotransformation, fertilizer, agroindustrial waste, substrate, aerobic fermentation

\section{INTRODUCTION}

Currently, Ecuador produces 4.06 million metric tons/year (tnm/year) of Solid Urban Waste (SUW) and per capita production of $0.74 \mathrm{~kg}$. Of these, $61.4 \%$ corresponds to organic matter being the main component of the SUW (Cabello, 1996). It is estimated that by 2017 the country will generate $5.4 \mathrm{mln}$.tons/year which is why it is necessary to implement a comprehensive waste management (Anonymous, 2016). According to information issued in the department of environment, health and hygiene of the city of Riobamba-Chimborazo it was determined that around 140 tons/day of garbage is collected, the same that is deposited without any previous treatment in the dumps open sky (Jara, 2016).

In the agroindustry, raw materials are subjected to adaptation or transformation processes to add value, generate large volumes of Solid Waste (SW) and effluents daily. The SW when they accumulate and do not return to nature, produce pollution, constituting one of the main environmental problems due to the production of high organic waste (Cury et al., 2017).

The agroindustrial activity in Ecuador annually produces thousands of tons of waste that contaminate the soil and water sources others will increase garbage dumps becoming sources of pollution. Currently, the environmental issue is immersed in discussions at all levels in addition caring for nature is part of the policies of the governments of Latin America, so, these governments draft documents that indicate the increase of "Efforts in the countries of the region to improve the articulation and compatibility of industrial policies, energy and environmental" (Anonymous, 2012).

The large amount of organic waste generated by the Ecuadorian agro-industry where some of this waste, rarely treated is thrown into open dumps and becomes a source of contamination due to its high content of biosolids an appropriate medium for the growth of an infinity of

Corresponding Author: Clemencia O. Merino, Centro de Investigacion y Desarrollo Biotecnologico,

Departamento de Investigacion, Facultad de Ciencias Agropecuarias Recursos Naturales y del Ambiente, Universidad Estatal de Bolivar, CP-020150 Guaranda, Ecuador 
microorganisms, vectors, rodents and other pests. At present these residues represent an important environmental and public health problem (Acosta et al., 2015).

Currently, one of the main problems faced by farmers is the high cost of external inputs such as synthetic fertilizers and agrochemicals which also cause serious problems of environmental pollution, soil degradation. A sustainable alternative for farmers and businesses is the production of compost from vegetable waste and animal manure (guano) using Effective Microorganisms (EM)

Keep in mind that microorganisms are very important in the cycle of transformation of matter and energy. They are responsible for degrading animal and plant remains, transforming them into essential nutrients for their own metabolism as well as generating substances and minerals that will serve as a source of energy for other species within the cycles (Garcia, 2004).

In this regard, Toalombo (2012) indicates that MS are biological products in which several types of beneficial microorganisms coexist as: bacteria (photo trophic, lactic and photosynthetic acids) actinomycetes (Nocardia) and fungi (Saccharomyces cereviseae). These effective microorganisms when they come into contact with organic matter secrete beneficial substances such as vitamins, organic acids, chelated minerals and fundamentally antioxidant substances.

The EM as microbial inoculants are used in the elaboration of bio-fertilizer (compost which consists of the biodecomposition and stabilization of an organic substrate under conditions that allow the development of temperatures in the thermophilic range as a result of the biological exothermic biological process for produce a more stable final product free of pathogens and weed seeds, likewise, inoculated in soils it promotes the fermentative decomposition that produces beneficial substances, restoring the microbiological balance of the soil, optimizing its physical and chemical conditions and achieving surprising results in agriculture by increasing the vigor of the soils and consequently increasing the production and productivity of the crops (Ninco and Sanchez, 2017).

One of the techniques that allows this controlled biodegradation of organic matter prior to its integration into the soil is composting and the final product is known as compost. For this reason, one of the alternatives for the use of this waste is the production of bio-fertilizer in the shortest time using the technology of the EM for the transformation of the agroindustrial waste horticultural fruit by aerobic digestion, therefore in the present investigation the following objectives were set: to establish the best percentage of EM-A in the production of bio-fertilizer in terms of yield as well as to determine which of the agro-industrial fruit waste types was the best for the crops.

\section{MATERIALS AND METHODS}

The present research work was carried out in the "Quintul" orchard, located in the city of Riobamba. The experimental materials used were the fruit peels of: tree tomato (Solanum betaceum), naranjilla (Solanum quitoense Lam) and tamarind (Tamarindus indica), vegetable waste, potatoes (Solanum tuberosum L.) and cauliflower (Brassica oleracea var. botrytis), the effective microorganisms, yeasts (Saccharomyces cerevisiae) and lactic acid bacteria (Lactobacillus) (EM-1). The factors and treatments that were applied. Study factors of the experiment; Factor A: agroindustrial waste fruit and vegetables $A_{1}=80 \%$ fruit waste $+20 \%$ of substrates of materials $(9.09 \mathrm{~kg}$ fruit waste $+1.14 \mathrm{~kg}$ of chips $+0.57 \mathrm{~kg}$ of blood $+0.57 \mathrm{~kg}$ of ash), $\mathrm{A}_{2}=80 \%$ waste of vegetables + $20 \%$ of substrates of materials $(9.09 \mathrm{~kg}$ waste of vegetables $+1.14 \mathrm{~kg}$ of chips $+0.57 \mathrm{~kg}$ of blood $+0.57 \mathrm{~kg}$ of ash) $\mathrm{A}_{3}=40 \%$ fruit waste $+40 \%$ vegetables $+20 \%$ substrates of materials (4.55 kg fruit waste $+4.55 \mathrm{~kg}$ vegetable waste $+1.14 \mathrm{~kg}$ of chips $+0.57 \mathrm{~kg}$ of blood $)+0.57$ $\mathrm{kg}$ of ash); Factor B: \% de EIM (Efficient indigenous microorganisms) $\mathrm{B}_{1}: 5 \%$ solution EIM $\mathrm{B}_{2}: 10 \%$ solution EIM.

Obtaining biofertilizer based on agro-industrial waste: For the experimental part was used wastes of fruits and vegetables of the agroindustrial companies "Mis frutales" and confectionery "El Mana", the EM-1 was acquired from the company "Agearth-Ecuador", the molasses of distribuidora "Carguacundo", the chip was acquired from carpentry ash for domestic use and water from the picin irrigation board. Description of the process of obtaining biofertilizer.

Activation of EM: For this stage, a ratio of 1:1 of molasses was used by EM for $18 \mathrm{~L}$ of water without chlorination in a tank of $30 \mathrm{~L}$ and allowing to stand for 7 days, the $\mathrm{pH}$ was measured using a pH meter (Hanna, H199111, EE-UU). After the activation of the MS, the raw material was received from Industrial "Mis frutales" and vegetables from the artisanal confectionery producer "El Mana". After that, the manual selection of the organic matter received using plastic bags (capacity 45, $45 \mathrm{~kg}$ ) was carried out. Seeds, barks and inorganic waste were classified in order to increase the acidity of the organic matter. The selected material was weighed then crushed in a manual mill (Corona, Ecuador) to facilitate the decomposition process. The formulation was made only 
once at the beginning of the experiment according to the following formula: for each $80 \%$ of waste $+20 \%$ of substrate was placed 5 and $10 \%$ of activated EM and water.

Aerobic digestion: In this phase the microorganisms transformed the horticultural fruit residues, stabilizing these organic substrates, under conditions of strictly controlled humidity as well as the $\mathrm{pH}$, Carbon Nitrogen $(\mathrm{C} / \mathrm{N})$ ratio and the amount of organic matter that allowed the development of temperatures in the thermophilic range as a result of the exothermic aerobic biological process to generate a more stable (bio-fertilizer) final product free of pathogens and weed seeds that can be applied to the soil in a beneficial way. Then it was dried in wooden boxes at room temperature this phase was carried out for 2 days. Then, we proceeded to the packaging and sealing. Finally, it was stored in a dry place.

Activated analysis of EIM: The $\mathrm{pH}$ of an MS sample was measured using a $\mathrm{pH}$ meter at the beginning and end of the activation process to determine the optimum level of EIM for aerobic digestion of organic matter.

Analysis of raw material: The $\mathrm{pH}$ of the raw material was measured at the beginning of the experiment in three samples to compare with the final product. Three samples of fruit waste, vegetables and the mixture of fruit and vegetable waste were taken to perform the carbon nitrogen analysis. Moisture was determined in terms of the percentage of 3 samples at the beginning of the experiment in order to provide adequate conditions for the proper development of microbiological activity.

Analysis of the finished product: After the elaboration phase of the bio-fertilizer we proceeded to measure its weight in $\mathrm{kg}$. Within the physical analyzes, the sensory analysis of color, odor and texture was performed on the 6 treatments with 3 repetitions each through a panel of previously trained evaluators. Using a scale of 1-4 to appreciate each of the mentioned attributes this according to $\mathrm{INEN}$. The tasters fulfilled the following conditions:

- Individuality among panelists, so, that there is no influence between them

- That they have not ingested alcoholic beverages before $48 \mathrm{~h}$ at the valuation

- That there is no family relationship or affinity with researchers

Chemical analysis in the finished product (Table 1).
Table 1: Chemical analyzes in the finished product

\begin{tabular}{ll}
\hline Analysis & Standard \\
\hline Determination of total phosphorus & NTE. INEN 0227:1978 \\
Potassium & NTE 0234:1978 \\
Calcium & NTE 0238:1978 \\
Total nitrogen & $0224: 1998$ \\
pH: & Method No. 4500-H+B \\
MO:EPA & SW-846 Wet \\
& oxidation/Walkley and Black \\
Electric conductivity & Units uS/cm C.E:EPA 9045 \\
Determination of magnesium & NTE 0239:1978 \\
& (LABCESTTA-ESPOCH) \\
\hline
\end{tabular}

Analysis of the best treatment: For the determination of the best treatment, the results obtained in the analysis of macro and micro elements were used as a reference to the 6 treatments of biofertilizer taken after the harvest at 20 days and the analysis of the Tukey test at 5\% to determine the yield in $\mathrm{kg}$ applied to the results of the treatments.

Analysis of macro and micronutrients: In the macro and micronutrient analyzes, the data obtained through the laboratory analysis were compared with the ranges established by the international quality standards for solid organic amendments.

Microbiological analysis: The best treatment was carried out at the end of the bio-fertilizer production process to determine the presence of pathogenic microorganisms that can affect the characteristics of organic fertilizer. All the analyzes were carried out in the soil laboratory, LABCESSTA and the Department of Biological Sciences of the Escuela Superior Politecnica de Chimborazo (ESPOCH).

Statistical analysis: A Design of Completely Random Blocks (DBCA) was made in factorial arrangement $3 \times 2$ with 3 replicas that responds to the following mathematical model:

Mathematical model: $\mathrm{Y}_{\mathrm{ij}} \mathrm{k}=\mu+\mathrm{A}_{\mathrm{i}}+\mathrm{B}_{\mathrm{j}}+\mathrm{AB}_{\mathrm{ij}}+\varepsilon_{\mathrm{ij}} \mathrm{k}$

Where:

$\mathrm{Y}_{\mathrm{ij}} \mathrm{k}=$ Any variable subject of measurement

$\mu=$ General average

$\mathrm{A}_{\mathrm{i}} \quad$ = Effect of factor A (mixture of organic matter)

$\mathrm{B}_{\mathrm{j}} \quad=$ Effect of factor $\mathrm{B}$ ( $\%$ of accelerator)

$\mathrm{AB}_{\mathrm{ij}}=$ Effect of interaction $\left(\mathrm{A}^{*} \mathrm{~B}\right)$

$\varepsilon_{\mathrm{ij}} \mathrm{k}=$ Effect of experimental error

\section{RESULTS AND DISCUSSION}

The $\mathrm{pH}$ was measured in the irrigation water, boiled irrigation water, boiled irrigation water plus molasses, 
Table 2: $\mathrm{pH}$ analysis in the activation of EIM

\begin{tabular}{lll}
\hline Description & Code & $\mathrm{pH}$ \\
\hline Irrigation water (Agua de riego) & $\mathrm{Ar}$ & 9.35 \\
Boiled water (Agua hervida) & $\mathrm{Ah}$ & 9.31 \\
Water+molasses (Agua+melasa) & $\mathrm{Am}$ & 6.66 \\
Water+molasses+EM-1 (Agua+melaza+EM-1) & $\mathrm{Ame}$ & 5.60 \\
Efficient microorganisms-activated & $\mathrm{EM}-\mathrm{A}$ & 3.90 \\
\hline
\end{tabular}

Table 3: Analysis of $\mathrm{pH}, \mathrm{C} / \mathrm{N}$ and moisture of the raw material

\begin{tabular}{lccc}
\hline Identification & $\mathrm{pH}$ & $\mathrm{C} / \mathrm{N}$ & Humidity (\%) \\
\hline Fruit waste & 4.02 & 59 & 63.9 \\
Waste from vegetables & 4.71 & 20 & 86.2 \\
Fruit-horticultural waste & 4.20 & 37 & 71.5 \\
Fruit waste+substrate+EM-A & 6.06 & 36 & 64.2 \\
Vegetable waste+substrate+EM-A & 6.67 & 28 & 73.0 \\
Fruit-horticultural waste+substrate+EM-A & 5.77 & 27 & 76.2 \\
\hline
\end{tabular}

Table 4: Tukey test at $5 \%$ to compare averages of the weight of the bio-fertilizer

\begin{tabular}{lccc}
\hline Treatments & Int. A*B & Averages & Ranges \\
\hline T2 & A1B2 & 6.79 & A \\
T1 & A1B1 & 5.89 & AB \\
T5 & A3B1 & 4.68 & BC \\
T3 & A2B1 & 4.23 & C \\
T6 & A3B2 & 4.23 & C \\
T4 & A2B2 & 3.92 & C \\
\hline
\end{tabular}

boiled water plus molasses plus EIM and activated effective microorganisms. In Table 2, the results obtained are shown. In Table 2 , the $\mathrm{pH}$ of water for the activation of EM-A is analyzed in which it is observed that the irrigation water has a $\mathrm{pH}$ of 9.35 once subjected to the boiling process it decreases to 9.31 add molasses to the boiled water a $\mathrm{pH}$ of 6.66 is obtained with the addition of EM-A to the mixture of water plus molasses a $\mathrm{pH}$ of 5.6 was obtained after resting for 8 days under shade a decrease was observed progressive $\mathrm{pH}$ until it reaches 3.9 due to the biological and chemical activity of the microorganisms present in EM-1. Normally irrigation waters have a $\mathrm{pH}$ between 6.5-8.4 values outside this range indicate imbalances which can cause nutritional disorders or toxic effects (Pizarro, 1996).

When comparing the results of $\mathrm{pH}$ obtained in this research with that described by the association of graduates of the Anonymous (2012) where it is stated that the EM-A before its application must have a $\mathrm{pH}$ lower than 3.5 (optimum) to 4 it can be noted that the $\mathrm{pH}$ of 3.9 was in a suitable range for aerobic fermentation.

Analysis in the raw material: The analyzes that were performed on the raw material (horticultural fruit waste) were: $\mathrm{pH}$, carbon nitrogen and moisture ratio (Table 3 ). In Table 4 when analyzing fruit and vegetable waste without substrate or efficient local microorganisms a $\mathrm{pH}$ was observed ranging from 4.02-4.71, carbon nitrogen ratio from $20-59$ and humidity from $63.9-86.2 \%$. However, in the organic wastes with substrate and EM-A, the $\mathrm{pH}$ values increased in a range of 5.77 (Fruit-vegetable
waste+substrate+EM-A) to 6.67 (Vegetable waste+substrate+EM-TO). The data of the $\mathrm{C} / \mathrm{N}$ ratio was between 27-36 and the percentage of humidity was between 64.2 (Fruit waste+substrate+EM-A) and 76.2 (Fruit waste-horticulture+substrate+EM-TO). When comparing the results of $\mathrm{pH}$ obtained in the present investigation of $6.06,6.67$ and 5.57 it is determined that they are superior to those established by Sztern and Pravia (1996) of 5.5 who states that $\mathrm{pH}$ lower than that indicated inhibit the growth of most bacteria and actinomycetes. This increase in $\mathrm{pH}$ is due to the ash substrate ( $\mathrm{pH}:$ 9.5), likewise, the $\mathrm{C} / \mathrm{N}$ content of the samples of 36,28 and 27 compared with those described by Sztern and Pravia (1996) of 20-30 and (Benzing, 2001) from $30-35$, we observe that they are within the established range, except for the sample that has a $\mathrm{C} / \mathrm{N}$ ratio of 36 , the $\mathrm{C} / \mathrm{N}$ decrease is possibly due to the nitrogen and carbon content present in the fruit waste added to the high content of nitrogen in the blood meal of (N:13\%) and the R:C/N of the chip substrate 500/1.

The optimal humidity parameter cited by Roman et al. (2013) is $45-60 \%$ these authors state that for aerobic fermentation (composting process) the very humid material produces oxygen displacement and can lead to zones of anaerobiosis, the solution to the problem was the turning of the mixture and/or the addition of substrates with low moisture content and high carbon value such as shavings, blood meal or dried fruit waste. This means that the results obtained are controlled in this range.

\section{Results in the finished product}

Weight of the bio-fertilizer: After this analysis it is observed that the weight of the bio-fertilizer as an effect of the interaction of 3 types of residues with the EM-A there are significant differences in the treatment T2 $(80 \%$ of waste of fruit $+20 \%$ substrate of materials to $10 \%$ of EM-A) which reached the highest weight $(6.79 \mathrm{~kg})$ in relation to $\mathrm{T} 4(80 \%$ of vegetable waste plus $20 \%$ of substrate to $10 \%$ of EM-A) that reached $3.92 \mathrm{~kg}$. These differences they are due to the moisture content of the waste (Bravo et al., 2013) more than $80 \%$ of the composition of the fruits is water, likewise, $85 \%$ of the composition of the vegetables is made up of water (Fernandez, 2000).

Chemical analysis of bio-fertilizer: Six samples of biofertilizer were taken randomly, the results obtained are presented (Table 5).

Nitrogen concentration: Table 6 shows the nitrogen percentage of the bio-fertilizer, observing that $\mathrm{T} 2(80 \%$ fruit waste $+10 \%$ chip, $5 \%$ blood meal and $5 \%$ ash at $10 \%$ 
Table 5: Chemical analysis of the bio-fertilizer

\begin{tabular}{llccccccr} 
Treatment & Code & N $(\%)$ & P (\%) & K (\%) & Ca (\%) & Mg (\%) & C/N & pH \\
\hline T1 & BDF-5\%EM-A & 2.94 & 0.6 & 0.12 & 0.01 & 0.012 & 14.14 & 5.5 \\
T2 & BDF-10\%EM-A & 2.24 & 0.4 & 0.16 & 0.02 & 0.015 & 15.8 & 5.4 \\
T3 & BDH-5\%EM-A & 1.26 & 0.5 & 0.30 & 0.01 & 0.011 & 26.2 & 5.2 \\
T4 & BDH-10\%EM-A & 3.78 & 0.3 & 0.18 & 0.03 & 0.014 & 8.1 & 5.1 \\
T5 & BDFH-5\%EM-A & 1.82 & 0.5 & 0.13 & 0.02 & 0.012 & 19.1 & 5.2 \\
T6 & BDFH-10\%EM-A & 2.94 & 0.4 & 0.12 & 0.035 & 0.013 & 11.6 & 5.3 \\
\hline
\end{tabular}

(Laboratorio del Departamento de Suelos)

EM-A), T5 (40\% fruit waste +40 vegetable waste at 5\% EM-A) and T3 treatment with a formulation of $(80 \%$ vegetable waste $+10 \%$ chip, $5 \%$ blood meal and $5 \%$ ash content at $5 \%$ of EM-A) reached a nitrogen concentration of: $2.24,1.82$ and $1.26 \%$, respectively. When comparing these concentrations of nitrogen with that cited by Remache (2008) in the range of 1.6 and $2.7 \%$, Leblanc et al. (2007) with values of 1.3-1.4\%, Chandna et al. (2013) with values of 1.4 and $1.5 \%$ and the international quality standards for solid organic amendments of $0.5-2.5 \%$ it was observed that the concentration of nitrogen was within the established parameter. The concentration of $\mathrm{N}$ obtained in each of the treatments is possibly due to the substrate of blood meal added to the formulation due to its high nitrogen content (13\%) (Suquilanda, 2006).

Phosphorus concentration: In the analysis of phosphorus, it was observed that in $\mathrm{T} 1$ (80\% of fruit waste $+10 \%$ of chips, $5 \%$ of blood and $5 \%$ of ash to $5 \%$ of EM-A) was numerically superior to the rest of treatments with a concentration of $0.6 \%$, the lowest concentration was obtained in T4 $(80 \%$ of vegetable waste $+10 \%$ of chips, $5 \%$ blood meal and $5 \%$ of ash to $10 \%$ of EM-A. According to Remache (2008) the concentration of phosphorus for the biofertilizer has a range of: $0.2 \%-0.3 \%$, the values reached for the concentration of phosphorus in bio-fertilizers exceeded $(0.4 \%)$ those established by the researcher was produced by the addition of substrate ash and blood flour that has phosphorus (2\%) (Suquilanda, 2006) similar values were obtained by Leblanc et al. (2007) $(0.29-0.49 \%)$. On the other hand, in an investigation carried out in India by Chandna et al. (2013) they obtained values ranging from $0.8-1.2 \%$. The concentration differences are especially, due to the time of obtaining the bio-fertilizer.

Potassium concentration: The concentration of potassium in each of the treatments was evaluated, observing that $\mathrm{T} 3(80 \%$ of vegetable waste $+10 \%$ of chips, $5 \%$ of blood and $5 \%$ of ash to $5 \%$ of EM-A) is superior with a potassium concentration of $0.3 \%$ unlike T6 $(40 \%$ fruit waste $+40 \%$ vegetable waste $10 \%$ chip, $5 \%$ blood and $5 \%$ ash at $10 \%$ EM-A) presents $0.12 \%$. The results published by Remache (2008) of 1.5 and $2.1 \%$, Leblanc et al. (2007) of 1.35 and Chandna et al. (2013) of 1.0 and $1.1 \%$ were found to be higher than those obtained in this research, the deficiency of this macronutrient is possibly due to the low potassium concentration of the substrates (Suquilanda, 2006).

Calcium concentration: The calcium concentration was evaluated in each of the treatments, observing that the T6 ( $40 \%$ of fruit waste $+40 \%$ of vegetable waste $10 \%$ of chips, $5 \%$ of blood and $5 \%$ of ash to $10 \%$ of EM-A) reached the highest concentration of calcium $(0.035 \%)$ and the lowest level was obtained from T3 $(0.010 \%)$ which corresponds to $(80 \%$ vegetable waste $+10 \%$ chip, $5 \%$ blood and $5 \%$ of ash to $5 \%$ EM-A). The calcium concentrations described by Remache (2008) is 0.2 and $0.4 \%$, Chandna et al. (2013) of 0.13 and $0.14 \%$ are higher than those achieved in this work. The low content of this element in the bio-fertilizer is probably due to the low concentration of this mineral in the added substrate and the presence of other nutrients in the organic matter (Suquilanda, 2006).

Magnesium concentration: The magnesium concentration was analyzed in each treatment, observing the highest concentration in $\mathrm{T} 2$ ( $80 \%$ of fruit waste $+10 \%$ of chips, $5 \%$ of blood and $5 \%$ of ash to $10 \%$ of EM-A) with $0.015 \%$ and T3 $(0.011 \%)$, ( $80 \%$ of vegetable waste $+10 \%$ of chips, $5 \%$ of blood and $5 \%$ of ash to $5 \%$ of EM-A), the variation and the low concentration were located. of magnesium is probably due to the low content of nutrients in organic matter (Mortvedt, 2000).

Carbon nitrogen ratio: The concentration of the $\mathrm{C} / \mathrm{N}$ ratio in each of the treatments analyzed, reported $14.4 \%$ in the T1 treatment ( $80 \%$ of fruit waste $+20 \%$ substrate to $10 \%$ chip, 5\% blood and 5\%) \% ash to 5\% of EM-A) and $15.8 \%$ in the T2 $(80 \%$ of fruit waste $+20 \%$ of substrate to $10 \%$ chip, $5 \%$ of blood and $5 \%$ of ash to $10 \%$ of EM-A) in relation to the rest of the treatments that are outside the established range. When comparing the results of the $\mathrm{C} / \mathrm{N}$ 

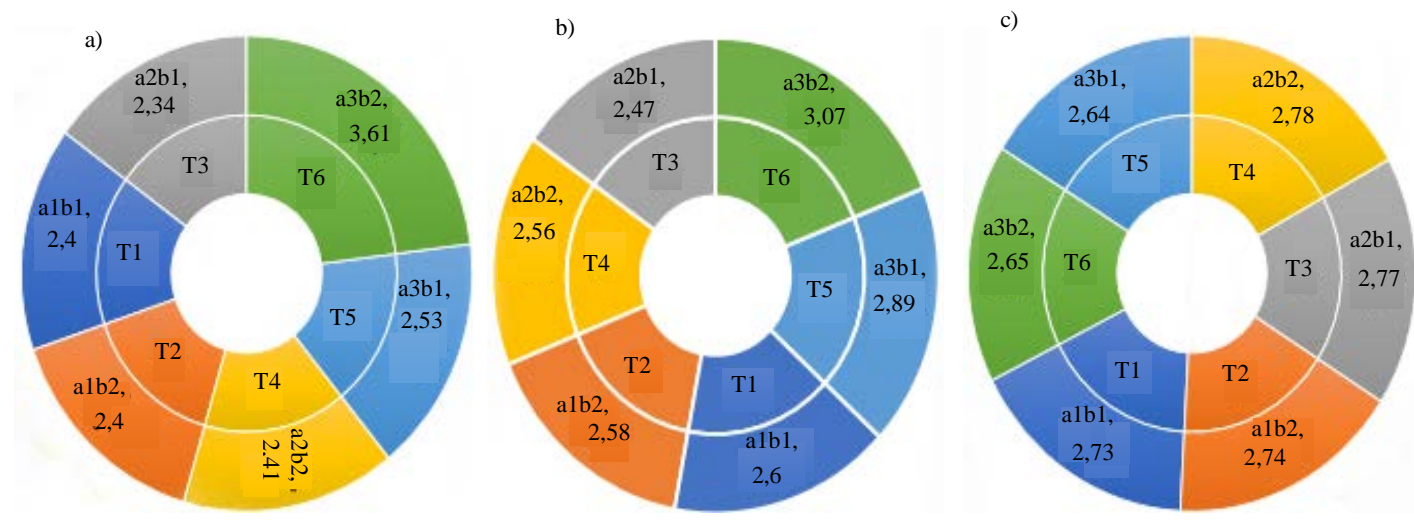

Fig. 1: Sensory indicators of mature biofertilizer; a) Color; b) Odor and c) Texture

ratio obtained in the present investigation (14.4 and $15.8 \%$ ) with those described according to Sztern and Pravia (1996) of 12-15\% and Leblanc et al. (2007) of 18\% it is appreciated that the $\mathrm{R}: \mathrm{C} / \mathrm{N}$ is located in an acceptable range in relation to the rest of the treatments this result is possibly due to the high concentration in the waste of fruits used $(\mathrm{C} / \mathrm{N}=36)$.

pH: The $\mathrm{pH}$ was analyzed, observing that this parameter is within the permissible limits, established by the International Quality Parameters for Solid Organic Amendments the T1 ( $80 \%$ fruit waste $+10 \%$ chip, $5 \%$ blood and $5 \%$ ). $\%$ of ash to $5 \%$ of EM-A), reached a $\mathrm{pH}$ of 5.5 and $\mathrm{T} 4(80 \%$ of vegetable waste $+10 \%$ of shavings, $5 \%$ of blood and $5 \%$ of ash to $10 \%$ of EM-A), obtained a pH of 5.1. The $\mathrm{pH}$ results obtained by Tognetti et al. (2008) were 7.7 and 8.7 in biocompost results higher than the one obtained in the present investigation (5.5) this fact is probably due to the fact that the analysis of the biofertilizer was carried out when its microbiological activity had not yet stopped.

Analysis of the sensory indicators of the bioabdomone obtained from fruit-horticultural waste: Color and appearance is the first contact the evaluator has. The smell is the sensation of acceptance of a stimulus by the sense of smell. The texture or appearance refers to the sensation that the touch produces with a certain material and in which the sense of touch is the main decoder of it, since, it is the vehicle in charge of producing the sensation that has the texture in matter of softness, hardness and roughness.

In Fig. 1, we analyzed the results obtained by the Tukey test at $5 \%$ to compare averages of the interaction $\mathrm{A}^{*} \mathrm{~B}$ there is no significant difference in any of the characters evaluated. However, the T6 treatment ( $40 \%$ of fruits +40 of vegetables $+20 \%$ of substrate to $10 \%$ of solution of EM.A) presents an average of 3.61 points corresponding to a dark color recommended for bioabsorbers, despite not be statistically different from the other treatments, mathematically exceeds in relation to the T3 treatment ( $80 \%$ of vegetable waste $+20 \%$ of substrate to $5 \%$ of EM-A) that registers 2.34 and represents a light color this is it owes to that the waste frutihortícolas when decomposing present a dark color and when applying a percentage of $10 \%$ of EM-A allowed a suitable decomposition and even a pleasant smell to the perception of the evaluators of the bio-fertilizer. Cervantes states that the organic fertilizer due to its dark color absorbs more solar radiation.

In odor, mathematically the T 6 treatment ( $40 \%$ of fruit and $40 \%$ of vegetables to $10 \%$ of solution of EM-A) allowed to register a value of 3.07 points that is equivalent to a product with a pleasant smell (moist earth) what does not happen with the rest of the treatments, especially, T3 ( $80 \%$ of vegetables $+20 \%$ of substrate and $5 \%$ of solution of EM-A) with which it reached a value of 2.47 points which is equivalent to an unpleasant odor. This is possibly due to the fact that vegetables in general do not have pleasant and marked smells and tastes like fruits (Brinton, 2000).

In texture, mathematically it was evidenced as the best treatment $\mathrm{T} 4$ ( $80 \%$ of waste of vegetables +20 of substrate of materials to $10 \%$ of solution EM-A) with an average of 2.78 valuation that approximates a bio-fertilizer of soft texture which indicates that $\mathrm{T} 4$ is the best in relation to the others. While the T5 treatment ( $40 \%$ of fruit waste $+40 \%$ of vegetable waste $+20 \%$ of substrate of materials to $5 \%$ of EM-A solution) obtained a lower valuation, evidencing that the factors used did not affect 


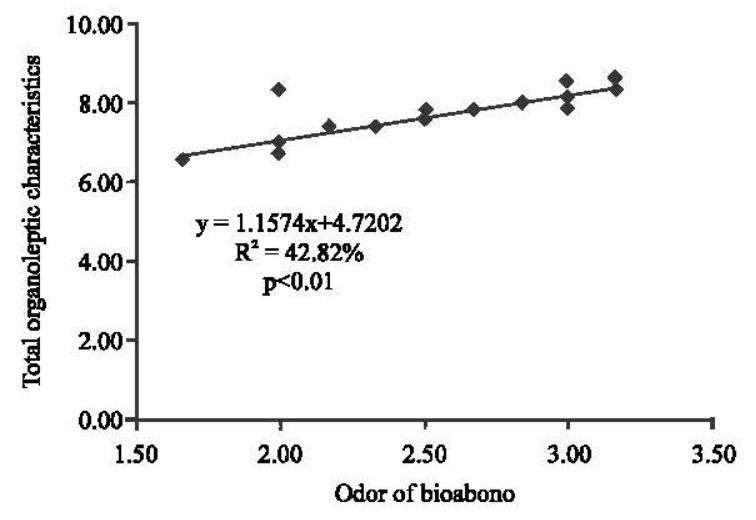

Fig. 2: Correlation and regression analysis

the results. According to the hedonic scale, the evaluation of the evaluators was 2.78 , close to soft (or light to the touch). The sensory indicators of the maturation criteria value the color, smell and appearance (texture) are reasonable criteria for the rejection of a compost that presents evident problems. The mature organic fertilizers must present a dark brown to black color, the smell of moist earth and when pressing with the hand is not compact but light to the touch and loose (Rodriguez and Giraldo, 2012), sensory indicators that coincide with the cited by the researchers.

Correlation and regression analysis of sensory bio-fertilizer evaluation: In Fig. 2 mention is made of the correlation and regression analysis of the odor indicator of the bio-fertilizer. In Fig. 2, it is observed that the sensory indicators of the agro-industrial waste biofilm depend significantly on the value of the smell attribute $(p<0.01) 42.82 \%$ of the sensory indicators depend on the odor and for each point that is detected. assigned to the smell attribute, the indicators are increased by 1.157 points.

Chemical analysis of the best treatment of bio-fertilizer: The content of macro and micro elements was analyzed for the best treatment of biofertilizer in order to determine its concentration of nutrients Table 6 . In Table 6 , the macro and microelement content of the best $\mathrm{T} 2$ bioabdominal treatment was analyzed ( $80 \%$ of fruit waste plus $20 \%$ of substrate to $10 \%$ of EM-A) according to the laboratory analysis it was determined that it corresponds to an alkaline product for the high concentration of calcium $(12800 \mathrm{mg} / \mathrm{kg})$ which is to mention that the present organic fertilizer can be used in acid soils that require improving the $\mathrm{pH}$ to neutral instead of using calcium carbonate. With regard to macronutrients it
Table 6: Results of the chemical analysis of the best treatment

\begin{tabular}{llc}
\hline Characteristics & Units & Concentration \\
\hline $\mathrm{pH}$ & $\mathrm{pH}$ & 8.53 \\
$\mathrm{P}$ & $\mathrm{mg} / \mathrm{kg}$ & 3900 \\
$\mathrm{~K}$ & $\mathrm{mg} / \mathrm{kg}$ & 15800 \\
$\mathrm{~N}$ & $\mathrm{mg} / \mathrm{kg}$ & 24600 \\
$\mathrm{Ca}$ & $\mathrm{mg} / \mathrm{kg}$ & 12800 \\
$\mathrm{Mg}$ & $\mathrm{mg} / \mathrm{kg}$ & 4300 \\
$\mathrm{Cu}$ & $\mathrm{mg} / \mathrm{kg}$ & 27.99 \\
$\mathrm{Fe}$ & $\mathrm{mg} / \mathrm{kg}$ & 3300 \\
$\mathrm{Zn}$ & $\mathrm{mg} / \mathrm{kg}$ & 69.05 \\
$\mathrm{~B}$ & $\mathrm{mg} / \mathrm{kg}$ & 15.55 \\
$\mathrm{Mn}$ & $\mathrm{mg} / \mathrm{kg}$ & 92.39 \\
$\mathrm{Mb}$ & $\mathrm{mg} / \mathrm{kg}$ & 0.96 \\
Organic material & $\%$ & 73.89 \\
\hline LABCESTTA-ESPOCH (2012) &
\end{tabular}

Table 7: Microbiological analy sis of the best bio-fertilizer treatment

\begin{tabular}{lll}
\hline Microorganism & Indicator & Normal range \\
\hline Nematodes (Ha) & Ausencia & $<2,00 \times 10^{9}$ \\
Bacteria CFU (g) & $3.37 \times 10^{9}$ & $1 \times 10^{8}-1 \times 10^{9}$ \\
Actinomycetes & $1.03 \times 10^{8}$ & $1 \times 10^{5}-1 \times 10^{8}$ \\
Funges (kg/ha) & 1670.00 & $500-5000$ \\
Humidity (\%) & 11.38 & \\
pH & 6.47 & \\
\hline
\end{tabular}

Laboratorio de Analisis Microbiologico-ESPOCH (2012)

should be mentioned that the product contains $\mathrm{N}: 24600$, P:3900 and $\mathrm{K}: 15800 \mathrm{mg} / \mathrm{kg}$ which indicates that the substrate has a good concentration of macroelements indispensable for crops, the content of nitrogen, phosphorus and potassium. Helps the foliar growth, development, maturity of flowers and fruits of the plant. Regarding microelements, bio-fertilizer contains Ca: $1.28 \%$, $\mathrm{Mg}: 92.39$, Cu:27.99, Fe:3300, Zn:69.05, B:15.55 and Mo: 0.96 , so, it can be pointed out that the product is suitable for any crop which requires these elements for its normal development. In organic matter the bio-fertilizer has a high concentration capable of retaining a large amount of water enough to dissolve the soil nutrients and fertilizer allowing the crops to express their production capacity in addition it allows to conserve the soil and to avoid the erosion by leaching in sandy soils (Table 7).

Microbiological analysis in the best bio-fertilizer treatment: After examining the microbiological content of the best $\mathrm{T} 2$ treatment it was observed that there is an absence of nematodes in the biofertilizer, however, it is necessary to state that it is normal to register up to $2 \times 109$ nematodes/ha for which this type of fertilizer can be accepted. The presence of bacteria that was recorded was $3.37 \times 109 \mathrm{CFU} / \mathrm{g}$ result that exceeds normal standards according to Camacho which possibly influences the quality of biofertilizer. The presence of actinomycetes in the fruit fertilizer was $1.03 \times 108$ a value that slightly exceeds that cited by Camacho this could cause problems in specific crops. In fungi, $1670 \mathrm{~kg} /$ ha was recorded which is within the limits allowed according to Camacho who 
cites that the permissible range of the fungal mass in fertilizers is $5005000 \mathrm{~kg} / \mathrm{ha}$ which is why you can indicate that this parameter is within the established limit.

\section{CONCLUSION}

In the evaluated variable, performance in the production of biofertilizer using the EM-A method it was determined that the best percentage of biofertilizer presented the T2 (A1B2) ( $80 \%$ fruit waste plus $20 \%$ of substrate to $10 \%$ of EM-A), reaching an average weight of $6.79 \mathrm{~kg}$ and a yield of $2.94 \mathrm{~kg} / \mathrm{m}^{2}$. According to the analysis of the sensory indicators it was determined that the T6 (A3B2) corresponding to ( $40 \%$ of fruit waste plus $40 \%$ of vegetable waste plus $20 \%$ of substrate to $10 \%$ of EM-A) was determined that in the color and texture indicator there were no significant differences at $\mathrm{p}=0.05$ in smell in factor A there was a highly significant difference at $p=0.01$. According to the physical and chemical analysis carried out on the 6 treatments of biofertilizer obtained it was established that the Carbon Nitrogen $(\mathrm{C} / \mathrm{N})$ ratio achieved $\mathrm{T} 1(\mathrm{~A} 1 \mathrm{~B} 1)$ and $\mathrm{T} 2$ with an average of 14.45 and $15.80 \%$, respectively, compared $\mathrm{C} / \mathrm{N}$ appropriate for agronomic use was shown to be within the acceptable range (12-15\%). In addition, T2 the values of $\mathrm{N}, \mathrm{P}, \mathrm{K}, \mathrm{Ca}, \mathrm{Mg}$ and $\mathrm{pH}$ were placed within the "International quality parameters for solid organic amendments" based on the described source established that the best treatment for radish cultivation (Raphanus sativus $\mathrm{L}$.) was the T2. Finally, the cost/benefit analysis of the capacity bioabdomon bag of $0.454 \mathrm{~kg}$ was established at a cost of $1.25 \mathrm{USD}$ with a gross profit of $0.30 \mathrm{US}$ cents that is to say that for every dollar invested a profit of 0.30 cents of USD was obtained.

\section{ACKNOWLEDGEMENTS}

We thank the State University of Bolivar, the Research Department which together with the debt swap project Ecuador-Spain have made it possible for this investigation to be carried out.

\section{REFERENCES}

Acosta, S.P., G.B. Zuniga, G.M. Shuguli, A.Z. Penafiel and A.C. Moina, 2015. [Utilization of agro-industrial waste for the production of microbial protein (In Spanish)]. Eur. Sci. J., 11: 1857-7881.

Anonymous, 2012. [Productive country]. Ministerio de Industrias y Productividad (MIPRO), Quito, Ecuador. (In Spanish)
Anonymous, 2016. [National program for the integral management of solid waste-PNGIDS ECUADOR]. Ministerio del Ambiente, Spain. (In Spanish) http://www.ambiente.gob.ec/programa-pngids-ecu ador/

Benzing, A., 2001. [Organic Agriculture-Fundamentals for the Andean Region (In Spanish)]. Neckar-Verlag, Villingen-Schwenningen, Alemania, ISBN:9783788319120, Page: 682.

Bravo, I., J.C. Montoya and J.C. Menjivar, 2013. Retention and availability of phosphorus associated with organic matter in a typic Melanudands of Cauca department, Colombia. Acta Agronomica, 62: 261-268.

Brinton, F.W., 2000. Compost Quality Standards and Guidelines: An International View. Wood End Research Laboratory Inc., New York.

Cabello, P.F., 1996. [High Frequency Localized Irrigations (RLAF): Drip, Microaspersion, Exudation]. Mundi-Prensa, Madrid, Spain, ISBN:9788471146106, Pages: 513 (In Spanish).

Chandna, P., L. Nain, S. Singh and R.C. Kuhad, 2013. Assessment of bacterial diversity during composting of agricultural byproducts. BMC Microbiol., Vol. 13. 10.1186/1471-2180-13-99

Cury, K., Y. Aguas, A. Martinez, R. Olivero and L.C. Ch, 2017. [Agroindustrial waste its impact, management and use (In Spanish)]. Colombian J. Anim. Sci., 9: 122-132.

Fernandez, J., 2000. [Agriculture and Livestock]. Editorial Oceano del Uruguay, Montevideo, Uruguay, Pages: 79.

Garcia, J., 2004. [The Efficient Microorganisms in Agricultura]. 95th Edn., Inside Ecuador Publisher S.A., Guayaquil, Ecuador, (In Spanish).

Jara, L., 2016. [Opportunities for valorization by composting organic waste of urban origin and related in ecuador: Management proposal for the province of Chimborazo]. Ph.D Thesis, Polytechnic School of Orihuela, Spain. (In Spanish)

Leblanc, H., M.E. Cerrato, A. Miranda and G. Valle, 2007. [Determination of the quality of organic fertilizers through bioassays (In Spanish)]. Trop. Earth, 3: 97-107.

Mortvedt, J.J., 2000. Bioavailability of Micronutrients. In: Handbook of Soil Science, Sumner, M.E. (Ed.)., CRC Press, Boca Raton, FL., pp: D71-S88.

Ninco, C. and J. Sanchez, 2017. [Proposal for the production of organic fertilizer through the composting of solid waste from El Rosal Municipality, Cundinamarca]. Master Thesis, University of America, Bogota, Colombia. (In Spanish) 
Pizarro, F., 1996. [High Frequency Localized Waterings]. Ediciones Larousse, Mexico, Page: 155 (In Spanish).

Remache, M., 2008. Organic Fertilizers. Lima Publisher, Lima Peru.

Rodriguez, J., and S. Giraldo, 2012. [Primer composting technique for domiciliary waste separated from the source]. Master Thesis, University of Antioquia, Medellín, Colombia. (In Spanish)

Roman, P., M. Martinez and A. Pantoja, 2013. [Manual of composting the farmer: Experiences in Latin America]. Master Thesis, Food and Agriculture Organization, Rome, Italy.
Suquilanda, M., 2006.. [Organic Agriculture]. 3rd Edn., Quito Publishing House, Quito, Ecuador, Page: 182 (In Spanish).

Sztern, D. and M. Pravia, 1996. [Manual for the preparation of compost]. Pan American Health Organization, Washington, USA. (In Spanish)

Toalombo, R., 2012. [Evaluation of efficient autochthonous microorganisms applied in the cultivation of white onion (Allium fistulosum)]. Master Thesis, Universidad Tecnica de Ambato, Ambato, Ecuador. (In Spanish)

Tognetti, C., M.J. Mazzarino and F. Laos, 2008. Compost of municipal organic waste: Effects of different management practices on degradability and nutrient release capacity. Soil Biol Biochem., 40: 2290-2296. 